\title{
К ВОПРОСУ СОВЕРШЕНСТВОВАНИЕ ПРИМЕНЕНИЯ МЕР АДМИНИСТРАТИВНОГО ПРЕСЕЧЕНИЯ В ДЕЯТЕЛЬНОСТИ ПОЛИЦИИ
}

\begin{abstract}
Аннотация: Реализация исполнительной власти, а также обеспечение общественного порядка находит свое практическое осуществление лишь непосредственно с помощью определенных способов и методов стратегического воздействия на сознание и поведение людей. В качестве этих способов на данном этапе развития общества выступают два взаимодополняющих метода государственного управления - убеждение и принуждение. Свое социальное назначение, а также эфрфективность своего воздействия данные методы находят в том, что они, во-первых, обуславливаются общими социально-экономическими закономерностями развития общества, во-вторых, обязательно должны находиться в неразрывном единстве, в-третьих, находятся в зависимости от того, насколько правильно и социально адекватно отражают требования жизни, экономические и политические потребности развития общества Государственно-правовое принуждение, как сочиальное явление, представляет собой многоаспектную юридическую категорию. В теории права государственное принуждение рассматривается прежде всего как средство (метод) организации волевых устремлений субъектов с целью подчинения государственной воле. Причем в широком смысле государственно-правовое принуждение рассматривается иногда как потенция неблагоприятных последствий в случае нарушения норм права, оказывающих предупредительное воздействие на психику Приведенные выше подходы выявляют особенности стадий процессов правового регулирования: правовые нормы лишь могут предусматривать возможность государственного принуждения, на самом деле, в реальной ситуации оно, опосредовавшись в праве, выступает в форме правового принуждения, выражаясь в конкретных принудительных мерах, и применяется компетентными государственными органами в ходе осуществления специальной деятельности по применению права.
\end{abstract}

Ключевые слова: пресечение, принуждение, полиция, сотрудник, ОВД, законность, администрация, вред, воздействие, назначение.

B системе государственного управления Российской Федерации для обеспечения законности и правопорядка используются различные правовые и организационные средства, которые по-разному воздействуют на участников соответствующих отношений. Выбор методов регулирования деятельности участников публичноправовых отношений зависит от их места и роли в организации управления, целей и задач, которые перед ними стоят, а также от правомерности или противоправности их поведения. Традиционно в управленческих отношениях используются методы убеждения и принуждения. Каждый из этих методов применяется исходя из складывающейся обстановки, а также той цели, которую ставит перед собой соответствующий правоприменитель. В полицейской деятельности используются методы управления, которые характерны для деятельности полиции, а также обеспечения правопорядка.

Полиция, как самый универсальный правоохранительный орган, реализует комплекс стимули- рующих методов, а также целую систему методов принуждения, которые при наличии воли государства заставляют физических и юридических лиц соблюдать установленные законом запреты и ограничения. Таким образом, государственное принуждение занимает центральное место в деятельности полиции. Именно посредством принуждения в большинстве случаев осуществляется противодействие преступлениям и административным правонарушениям. Государственное принуждение весьма неоднородно. Оно дифференцируется на ряд групп. Центральное место в системе государственного принуждения занимают меры административного пресечения.

Административное принуждение реализуется большинством служб и подразделений полиции. В этой связи в настоящее время, как никогда, актуальна проблема совершенствования правового регулирования реализации мер административного пресечения, а также создание эффективного механизма их применения в полицейской деятельности. 
Меры административного пресечения, реализуемые в деятельности полиции, носят разнообразный характер. Эти меры подкрепляют правоохранительный потенциал различных мер административного предупреждения, дают возможность выявлять преступления и административные правонарушения, а также обеспечивают применение административных наказаний.

Большое значение применению мер административного пресечения в комплексе добавляет и тот факт, что в настоящее время имеется достаточно много правовых и организационных проблем, связанных с осуществлением сотрудниками полиции административных задержаний, применения физической силы, специальных средств, а также огнестрельного оружия на основании Федерального закона «О полиции» и др.

На основе анализа и обобщения административного законодательства, научной литературы по исследуемой проблеме, а также соответствующей правоприменительной деятельности органов внутренних дел представляется возможным сделать вывод о том, что актуальность исследования выше обозначенной проблемы обусловлена целым рядом обстоятельств. К числу которых относится стремление нашего государства создать эффективные рыночные отношения и определить степень их адекватного административно-правового регулирования со стороны государства, сформировать административно-правовой механизм, направленный на реализацию конституционных положений, касающихся обеспечения прав и законных интересов личности в сфере внутренних дел, а также обеспечить безопасность личности, общества и государства.

В этой связи меры административного пресечения, реализуемые сотрудниками полиции - это составная часть системы административного принуждения, включающая организационные, словесно-психологические, имущественные и организационные средства, которые реализуются при наличии отклоняющего поведения физических и юридических лиц, возникновении обстоятельств техногенного, природного и иного характера и направленных на предупреждение различных правонарушений и процессуальное обеспечение применения административных и уголовных наказаний.

Нужно отметить, что применение любых мер административного пресечения сотрудниками полиции преследует цели, связанные с достижением определенного результата правоприменительной деятельности. Но во всех случаях меры административного пресечения выполняют роль право- охранительных функций, являются средством реализации административно-правовых запретов и ограничений установленных в сфере внутренних дел. Как средство прекращения противоправного поведения, способа устранения противоправной ситуации меры административного пресечения играют важную роль в охране общественного порядка и обеспечении общественной безопасности. Следует также отметить, что меры административного пресечения по своему характеру и целевому назначению весьма многочисленны и разнообразны. Ряд мер административного пресечения не встречаются в другой отрасли российского права, а известны только административному праву.

В этой связи меры административного пресечения, реализуемые сотрудниками полиции, могут быть классифицированы исходя из степени их процессуальной и организационной самостоятельности, форме предписания, цели и методу воздействия, имущественных последствий, объекта воздействия, а также уровня нормативного правового регулирования.

Основаниями применения мер административного пресечения сотрудниками полиции являются угрозы техногенного, природного, биологического и социального характера. Угрозы обозначенных выше явлений, а также пресечения их возникновения, развития и разрастания обуславливает необходимость обеспечения безопасности личности и общества и тем самым требует применения мер административного пресечения. Помимо этого, основаниями применения мер административного пресечения является оценка складывающейся обстановки, которая требует вмешательства в ее разрешение органов и должностных лиц исполнительной власти, а также применения мер административного пресечения с их стороны. Следует отметить, что оценка складывающейся обстановки является правовой, поскольку оно опирается на нормы закона, но вместе с тем, содержит в себе и элементы усмотрения со стороны должностных лиц исполнительной власти.

Механизм реализации мер административного пресечения в деятельности сотрудников полиции конструктивно включает правовые, организационные, технические, социально-психологические, а также процессуальные компоненты ${ }^{1}$.

В целях обеспечения права лица, подвергнутого административному задержанию сотрудника-

\footnotetext{
Костенников М.В. Административная деятельность органов внутренних дел. Особенная часть. - М., 2003.
} 
ми полиции, в законе «0 полиции» (ст. 14) , а также КоАП РФ (ст. 27.3) закрепить обязанность сотрудника полиции предоставить задержанному гражданину реализовать предоставленное ему право на телефонный звонок своим родственникам, знакомым о факте задержания и месте нахождения. В этой связи в законе «0 полиции» было вполне оправдано закрепить предписание, обязывающее должностных лиц, которые осуществили задержание, предоставить задержанному право сообщить лично по теле-

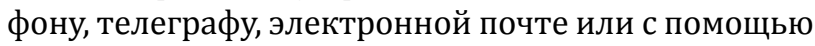
других средств связи о факте и основаниях задержания, месте его нахождения и др. В бланке протокола о задержании, по нашему мнению, следует предусмотреть графу о том, что гражданин воспользовался предоставленным правом и сообщил о своем задержании соответствующим способом. В протоколе задержания гражданин должен расписаться в том, что ему было предоставлено право лично сообщить о своем задержании и месте нахождения. Необходимо также четко определить, через какое время задержанному гражданину будет предоставлена возможность сообщить о том, что он задержан. Такое право может быть предоставлено задержанному гражданину сразу после составления протокола о задержании или одновременно с регистрацией его в книге задержанных граждан.

Для создания эффективных механизмов пресечения административных правонарушений, сотрудникам полиции целесообразно предоставить право вхождение (проникновение) в жилые и иные помещения, на земельные участки и территории физических и юридических лиц.

В законе «О полиции», а также КоАП России целесообразно определить виды административных правонарушений, для пресечения которых сотрудники полиции имеют право лично или в составе подразделения (группы) применять физическую силу и специальные средства. В настоящее время целесообразно унифицировать основания применения физической силы и специальных средств сотрудниками полиции как для пресечения преступлений, так и для пресечения административных правонарушений.
Для совершенствования реализации мер специального административного пресечения сотрудниками полиции в законе «О полиции» необходимо закрепление процессуальных требований, обеспечивающих их реализацию. В частности, целесообразно нормативно определить перечень процессуальных документов, в которых целесообразно закрепить оформление порядка применения физической силы, специальных средств, служебного огнестрельное оружие ограниченного поражения, а также огнестрельного оружия.

Применение мер административного пресечения осуществляется посредством реализации требований законности. Обеспечение законного применения мер административного пресечения сотрудниками полиции осуществляется при помощи гарантий и способов обеспечения законности, которые выступают самостоятельными образованиями по отношению к принципу законности, однако устанавливаются законодателем именно в соответствии с ним, а также с учетом особенностей непосредственного процесса применения мер административного пресечения ${ }^{2}$.

Показателем реально существующей законности при применении мер административного пресечения является последовательная и полная реализация всех ее элементов. К числу специфических признаков и требований законности при применении мер административного ресечения, относятся следующие: требования законности при применении мер административного пресечения характеризуют собой уровень развития нормотворчества, которое является материальной формой выражения принципа законности и представляет собой ее формальный показатель.

В целях обеспечения законности при применении мер административного пресечения в деятельности сотрудников полиции целесообразно минимизировать границы необоснованного усмотрения, а также более четко нормативно определить процедуру и тактику применения соответствующих мер государственного принуждения.

\section{Библиография:}

1. Коренев А.П. Административная деятельность органов внутренних дел. Часть особенная / А.П. Коренев [и др.]. - М.: Щит-М, 2003. - 342 с.

2. Капитонов С.А. Ведущая функция милиции / С.А. Капитонов. - М.: Юриспруденция, 2002. - 160 c.

2 См.: Куракин А.В. Актуальные проблемы науки административного права. - М., 2011. 
Административное и муниципальное право 1 (73) • 2014

3. Каплунов А.И. Применение и использование огнестрельного оружия / А.И. Каплунов, С.Ф. Милюков. - СПб.: Юридический центр Пресс, 2003. - 363 с.

4. остенников М.В. Административная деятельность органов внутренних дел. Особенная часть. / М.В. Костенников, А.В. Куракин. - М.: Щит-М, 2003. - 344 с.

5. Костенников М.В. Актуальные проблемы административно-правового регулирования / М.В. Костенников, А.В. Куракин. Т. 1. - М.: Маросейка, 2010. - 496 с.

6. Костенников М.В. Административный запрет как средство противодействия коррупции в системе государственной службы / М.В. Костенников, А.В. Куракин. - М.: ЮНИТИ-ДАНА, Закон и право, 2010. $-127 \mathrm{c.}$

7. Костенников М.В. Актуальные проблемы науки административного права / М.В. Костенников, А.В. Куракин. Т. 2. - М.: Маросейка, 2011. - 573 с.

8. Костенников М.В. Административный финансовый контроль в системе МВД России / М.В. Костенников, А.В. Куракин, В.Н. Кузнецов. - Домодедово: ВИПК МВД России, 2011. - 124 с.

9. Трегубова Е.В. Административные запреты в сфере осуществления полицейской деятельности // NB: Российское полицейское право. - 2013. - 1. - С. 25 - 44. URL: http://www.e-notabene.ru/pm/ article_718.html

10. Куракин А.В., Костенников М.В. Принципы организации и деятельности российской полиции // NB: Российское полицейское право. - 2013. - 2. - C. 22 - 49. URL: http://www.e-notabene.ru/pm/ article_799.html

11. Куракин А.В., Костенников М.В. Административно-правовое противодействие коррупции в системе государственной службы и в деятельности сотрудников полиции Российской Федерации и зарубежных государств // NB: Российское полицейское право. - 2013. - 1. - C. 65 - 83. URL: http://www.enotabene.ru/pm/article_735.html

\section{References (transliterated):}

1. Korenev A.P. Administrativnaya deyatel'nost' organov vnutrennikh del. Chast' osobennaya / A.P. Korenev [i dr.]. - M.: Shchit-M, 2003. - 342 s.

2. Kapitonov S.A. Vedushchaya funktsiya militsii / S.A. Kapitonov. - M.: Yurisprudentsiya, 2002. - $160 \mathrm{~s}$.

3. Kaplunov A.I. Primenenie i ispol'zovanie ognestrel'nogo oruzhiya / A.I. Kaplunov, S.F. Milyukov. — SPb.: Yuridicheskii tsentr Press, 2003. - 363 s.

4. Kostennikov M.V. Administrativnaya deyatel'nost' organov vnutrennikh del. Osobennaya chast'. / M.V. Kostennikov, A.V. Kurakin. - M.: Shchit-M, 2003. - 344 s.

5. Kostennikov M.V. Aktual'nye problemy administrativno-pravovogo regulirovaniya / M.V. Kostennikov, A.V. Kurakin. T. 1. - M.: Maroseika, 2010. - 496 c.

6. Kostennikov M.V. Administrativnyi zapret kak sredstvo protivodeistviya korruptsii v sisteme gosudarstvennoi sluzhby / M.V. Kostennikov, A.V. Kurakin. - M.: YuNITI-DANA, Zakon i pravo, 2010. - 127 s.

7. Kostennikov M.V. Aktual'nye problemy nauki administrativnogo prava / M.V. Kostennikov, A.V. Kurakin. T. 2. - M.: Maroseika, 2011. - 573 c.

8. Kostennikov M.V. Administrativnyi finansovyi kontrol' v sisteme MVD Rossii / M.V. Kostennikov, A.V. Kurakin, V.N. Kuznetsov. - Domodedovo: VIPK MVD Rossii, 2011. — 124 s.

9. Tregubova E.V.Administrativnye zaprety v sfere osushchestvleniya politseiskoi deyatel'nosti // NB: Rossiiskoe politseiskoe pravo. - 2013. - 1. - C. 25 - 44. URL: http://www.e-notabene.ru/pm/article_718.html

10. Kurakin A.V., Kostennikov M.V. Printsipy organizatsii i deyatel'nosti rossiiskoi politsii // NB: Rossiiskoe politseiskoe pravo. - 2013. - 2. - C. 22 - 49. URL: http://www.e-notabene.ru/pm/article_799.html

11. Kurakin A.V., Kostennikov M.V. Administrativno-pravovoe protivodeistvie korruptsii v sisteme gosudarstvennoi sluzhby i v deyatel'nosti sotrudnikov politsii Rossiiskoi Federatsii i zarubezhnykh gosudarstv // NB: Rossiiskoe politseiskoe pravo. - 2013. - 1. - C. 65 - 83. URL: http://www.e-notabene.ru/pm/article_735.html 